\title{
Zwei vergessene Texte Moritz Schlicks
}

\author{
von
}

\author{
Klaus Hentschel*
}

Bei Forschungen über die Beziehungen des Philosophen Moritz Schlick (1882-1936) zu Albert Einstein (1879-1955) und zu Schlicks Interpretation der Relativitätstheorie Einsteins ${ }^{1}$ fand ich zwei Texte Schlicks, die in der Standardbibliographie der Werke Schlicks ${ }^{2}$ nicht aufgeführt sind und auch in der Sekundärliteratur zu Schlick bislang keine Berücksichtigung erfuhren. Da beide Texte in heute schwer zugänglichen Büchern erschienen sind, werden sie im folgenden vollständig wiederabgedruckt und jeweils kurz kommentiert.

\section{Eine Selbstbiographie aus den dreißiger Jahren}

Ab 1931 unternahm Dr. Eugen Hauer die Aufgabe, das Eislersche Philosophen-Lexikon ${ }^{3}$ durch ein aktuelleres Verzeichnis zu ersetzen. Nach dem Tod von Hauer 1933 setzte Dr. phil. habil. Werner Ziegenfuss diese Aufgabe fort. ${ }^{4}$ An fast 700 deutschsprachige Philosophen wurden Rundfragen versandt, ca. 600 davon beantworteten diese. Unter den Philosophen, die für das geplante Lexikon Mitte der dreißiger Jahre auch eine knappe Darstellung der eigenen philosophischen Grundhaltung verfaßten, war auch Moritz Schlick, zu dieser Zeit Zentralfigur des sog. 'Wiener Kreises'. ${ }^{5}$ Nachdem das Lexikon bereits fast fertig gedruckt vorlag, mußte der Verlag eine weitere Veröffentlichung des Werkes aus politischen Gründen einstellen. ${ }^{6}$ Eine aktualisierte Version konnte deshalb erst nach Beendigung des 2 . Weltkrieges bei de Gruyter in Berlin 1949 erscheinen.

Schlicks Abriss seiner philosophischen Position, die er selbst als »konsequenten und völlig reinen Empirismus« bezeichnet, wurde offenbar nach der Wiederhinwendung zu "Fragen der Ethik" und Ästhetik ${ }^{8}$ verfasst, die sich im Schlickschen Oeuvre seit 1927, ver-

•Cankebeerstrasse 97, D-2988 Westdorf, BRD. 
stärkt seit 1934 vollzogen hatte. Deutlich zeigt sich ferner der Einfluß des in den dreißiger Jahren von Schlick geradezu verehrten Ludwig Wittgenstein,${ }^{10}$ der einmal namentlich und darüber hinaus auch durch Anspielungen auf Tractatus-Sätze angeführt wird. ${ }^{\text {" }}$ Es folgt jetzt der ungekürzte Teil des Artikels über Moritz Schlick, soweit von ihm selbst verfaßt; im Handwörterbuch der Philosophie nach Personen wurde er eingerahmt von Daten zur Person und einem ausgewählten Schriftenverzeichnis, die hier beide fortgelassen werden.

Sch. versucht die Begründung und den Aufbau eines konsequenten und völlig reinen Empirismus. Frühere Formen des Empirismus, von Sextus Empirikus bis zu Mill und Mach, waren weder rein noch konsequent, weil sie von Logik und Mathematik - dem "Rationalen« - keine befriedigende Rechenschaft geben konnten. Der neue Empirismus Sch.s geht aber gerade von dem Verständnis des mathematischen Denkens und seiner Anwendung auf die Wirklichkeit aus. Von dort gelangt die "Allgemeine Erkenntnislehre" mit Hilfe einer Analyse des Erkenntnisvorganges zunächst zu einer klaren Scheidung des Rationalen vom Empirischen, des Begrifflichen vom Anschaulichen. Begriffe sind bloße Zeichen, die der zu erkennenden Wirklichkeit zugeordnet werden; sie treten in den A Aussagen « in ganz bestimmter Weise geordnet auf, und diese vermögen dadurch bestimmte Strukturen der Wirklichkeit »auszudrücken*. Jede Aussage ist der Ausdruck einer Tatsache und stellt insofern eine $" E_{r}$ kenntnis « dar, als sie eine neue Tatsache mit Hilfe alter Zeichen beschreibt, also durch eine neue Kombination auch sonst schon verwendeter Begriffe. Die Ordnung der Wirklicbkeit, die sich auf diese Weise offenbart, wird allein durch Erfahrung festgestellt, es gibt mithin nur empirische Erkenntnis. Die sogenannten rationalen Wahrheiten also, die rein begrifflichen Sätze wie die logisch-mathematischen (aber auch die sog. phänomenologischen Sătze, wie etwa der, daß jedem Ton eine Intensität und eine Höhe zukomme) sind nichts als Zeichenregeln, welche die Syntax der Sprache bestimmen (L. Wittgenstein), in der wir von der Welt reden. Sie haben rein analytisch-tautologischen Charakter und enthalten daher keine Erkenntnis; sie sagen nichts uber die Wirklichkeit aus, aber gerade deswegen sind sie auf jede beliebige Tatsache der Welt anwendbar. So besteht Erkenntnis ihrem Wesen nach in einer Wiedergabe der Ordnung, der Struktur der Welt; der Stoff oder Inhalt, der diese Struktur besitzt, kann nicht in sie eingehen; denn das Ausdrückende ist eben nicht das Ausgedrückte selber. Es wäre also ein unsinniges Beginnen, den »Inhalt « selbst "ausdrücken« zu wollen. Damit ist jeder Metaphysik das Urteil gesprochen; denn gerade dies hat sie von jeher gewollt, indem sie sich das Ziel setzte, das eigentliche »Wesen des Seins« zu erkennen.

In der Ästhetik und Ethik führt der strenge Empirismus au dem Ergebnis, daß es keinen Sinn hat, von *absoluten« Werten zu sprechen; nur die bei den Menschen tatsächlich vorgefundenen wertenden Verhaltungsweisen können Gegenstand der Untersuchung sein. Auf diesem Standpunkte ergibt sich eine 
neue Begründung einer Art von Eudämonismus, dessen Moralprinzip ungefähr lautet: Mehre deine Glückseligkeit!

Die Philosophie ist keine Wissenschaft, obwohl sie alle Wissenschaften durchdringt. Während nämlich diese aus Systemen wahrer Sätze bestehen und Erkenntnis enthalten, besteht die Philosophie in der Aufsuchung des Sinnes der Sätze und schafft Verständnis, das zur Weisheit führt.

(Für das Lexikon dargestellt von Moritz Schlick.)

2. Der Higgins-Preis $1920 / 22$

\subsection{Zur Vorgeschichte der Preisausschreibung und über Schlicks Entscheidung zur Teilnahme}

1920 schlug Herr Eugene Higgins, ein wohlhabender Amerikaner, dem Scientific American, der einflußreichen populärwissenschaftlichen Zeitschrift Amerikas, vor, daß zur Förderung des besseren und breiteren Verständnisses der Relativitätstheorie Einsteins ein Preis für eine im Umfang auf 3000 Worte beschränkte populär gehaltene Schrift ausgesetzt werden sollte. Nachdem 1919 die verallgemeinerte Relativitäts- und Gravitationstheorie Einsteins durch englische Messungen der Lichtablenkung an der Sonnenoberfläche bei einer Sonnenfinstemis bestätigt worden war, konnte mit großer Resonanz für das Preisausschreiben gerechnet werden. Den Aufruf in der Ausgabe des Scientific American vom 18. September 1920 las auch Moritz Schlick, der drei Wochen später, am 9. Oktober 1920 an Albert Einstein, mit dem er seit 1915 in Korrespondenz stand, folgendes schrieb:

Erzählte ich Ihnen schon, daB ich mich an dem Preisausschreiben des 'Scientific American' für eine populäre Darstellung Ihrer Theorie beteiligt habe? Es hat mich viel Schweiß gekostet, wegen der 3000 Wort-Schranke, aber der Preis is so enorm hoch ( 5000 Dollar), $\mathrm{daB}$ ich glaubte, es selbst bei äußerst geringen Chancen versuchen zu sollen: der Familie wäre gleich für eine Reihe von Jahren weiter geholfen. ${ }^{14}$

Zu diesem Zeitpunkt war Schlick noch Professor in Rostock, wo er sich 1911 habilitiert hatte, ${ }^{15}$ doch schon 1921 wechselte er auf eine freiwerdende Professur in Kiel und ein Jahr später dann auf den ehemaligen Lehrstuhl Machs nach Wien. ${ }^{16}$ Die geringe Dotierung 
seiner Rostocker Professur und die ohnehin miserable Situation der deutschen Nachkriegswirtschaft machen verständlich, wieso Schlick sich der 'Schweißarbeit' unterzog. Schlicks Manuskript traf als 18. von insg. ca 275 ernstzunehmenden Einsendungen in Amerika ein und gelangte auch noch in die Gruppe der engeren Wahl (17 Einreichungen). ${ }^{17}$

Die Wahl der Preisrichter Leigh Page (Yale) und Edwin Plimpton Adams (Princeton) fiel jedoch auf den Angestellten des Britischen Patentamtes, Lyndon Bolton; offenbar wegen zu starkem Überlapp der Inhalte des Schlickschen Manuskriptes mit anderen Einsendungen wurde Schlicks Aufsatz dann auch nicht, wie 15 andere der besten Arbeiten, vollständig abgedruckt in der vom Redakteur des Scientific American edierten Auswahl unter den Einsendungen. ${ }^{18}$ Jedoch wurden dort einige ausgewählte Passagen des Schlickschen Manuskriptes in Abschnitten wiedergegeben, die aus kurzen Extrakten der Einreichungen vieler Mitbewerber zusammengestellt worden sind. ${ }^{19}$ Diese werden im folgenden wiedergegeben und dann kurz kommentiert. ${ }^{20}$

\subsection{Veröffentlichte Auszüge aus Schlicks Einreichung zum Higgins- Preis $1920 / 22$}

When we speak of a body as being "in motion", we mean that this body is changing its position "in space". Now it is clear that the position of an object can only be determined with reference to other objects; in order to describe the place of a material thing we must, for example, state its distance from other things. If there were no such bodies of reference, the words "position in space" would have no definite meaning for us. (S. 46)...

What is true of "place" must be true also of "motion", since the latter is nothing but change of place. In fact, it would be impossible to ascribe a state of motion or of rest to a body poised all alone in empty space. Whether a body is to be regarded as resting or as moving, and if the latter at what speed, depends entirely upon the objects to which we refer its position in space. (S. 47)...

We can express all this by saying "All motions are relative; there is no such thing as absolute motion'"). This line of argument has in fact been followed by many natural philosophers. But is its result in agreement wich actual experience? Is it really impossible to distinguish between rest and motion of a body if we do not take into consideration its relations to other objects? In fact it can easily be seen that, at least in many cases, no such distinction is possible.

Who is moving? ${ }^{21}$

Imagine yourself sitting in a railroad car with veiled windows and running on 
a perfectly straight track with unchanging velocity: you would find it absolutely impossible to ascertain by any mechanical means whether the car were moving or not. All mechanical instruments behave exactly the same, whether the car be standing still or in motion. (S. 48ก)...

Any changes of speed or of direction (as when the car speeds up or slows down or rounds a curve) can be detected by observing the behaviour of bodies in the car, without apparent reference to any outside objects. This becomes particularly obvious with sudden irregularities of motion, which manifest themselves by shaking everything in the car. But a uniform motion in a straight line does not reveal itself by any phenomenon within the vehicle. (S. 49)...

So we can enunciate the following principle: When a body is in uniform rectilinear motion relatively to a second body, then all phenomena take place on the first in exactly the same manner as on the second; the physical laws for the happenings on both bodies are identical. (S. 50)

Hiermit schließt die erste Gruppe der als von Schlick stammend gekennzeichneten Abschnitte; es folgen neben umfangreichen Einschüben des Editors Ausschnitte aus Einsendungen u.a. von L. L. Whyte, R. B. Lindsay, A. d'Abro u. vielen anderen, heute nicht mehr bekannten englischsprachigen Einsendern. Nach einer Diskussion der verschiedenen Beschreibungen ein und desselben Vorganges aus relativ zueinander bewegten Bezugssystemen, die aus anderen Einreichungen zusammengestellt wurden, führte der Herausgeber J.M. Bird die zweite Gruppe von Zitaten aus Schlicks Manuskript an, die jetzt folgt.

Who is right? According to the principle of relativity a discussion on this question is absolutely impossible. Both parties are right from their own points of view; and we must admit that two events in two different places may be simultaneous for certain observers, and yet not simultaneous for other observers who move with respect to the first ones. There is no contradiction in this statement, although it is not in accordance with common opinion, which believes simultaneousness to be something absolute. But this common opinion lacks foundation. It cannot be proved by direct perception, for simultaneity of events can be perceived directly. ${ }^{22}$ (S. 90)...

Only if they happen at the same place; if the events are distant from each other, their simultaneity or succession can be stated only through some method of communicating by signals. There is no logical reason why such a method should not lead to different results for observers who move with regard to one another.

From what we have said, it follows immediately that in the new theory not only the concept of simultaneousness but also that of duration is revealed as dependent on the motion of the observer. (S.90)... 
Two physicists who measure the duration of a physical process will not obtain the same result if they are in relative motion with regard to one another.

They will also find different results for the length of a body. An observer who wants to measure the length of a body which is moving past him must in one way or another hold a measuring rod parallel to its motion and mark those points on his rod with which the ends of the body come into simultaneous coincidence. The distance between the two marks will then indicate the length of the body. But if the two markings are simultaneous for one observer, they will not be so for another one who moves with a different velocity, or who is at rest, with regard to the body under observation. He will have to ascribe a different length to it. And there will be no sense in asking which of them is right: length is a purely relative concept, just as well as duration. (S.91)

Weitere wörtliche Übernahmen von Passagen des Schlickschen Manuskriptes finden sich in der veröffentlichten Auswahl leider nicht. Noch kurz einige erläuternde Bemerkungen zu dem vorangegangenen Text:

Der erste Abschnitt ist bereits sehr kennzeichnend für Schlicks Argumentation: ausgehend von der Frage, wie die Position eines Objektes im Raum festgestellt wird, kommt er zu der Aussage, daß das Vorliegen von Bezugskörpern für die Bedeutung der Worte 'Position im Raum' unentbehrlich ist. Er spricht also über die (sprachlichen) Vorbedingungen für die Sinnhaftigkeit eines Wortes eher als über ein physikalisches Faktum.

Im dritten Abschnitt fällt der Bezug auf eine Argumentationslinie auf, die schon von vielen »natural philosophers« verfolgt worden sei auch ohne die Nennung von Namen ist klar, daß hier Berkeley und vor allem Mach gemeint sind $;^{23} \mathrm{da} B$ beide nicht namentlich erwähnt sind, hat vermutlich den Grund darin, daß Schlick und seine Wiener und Berliner Kollegen zwar die Wurzeln ihrer Auffassung gerne auf Mach zurückführten, ${ }^{24}$ aber in ihren erkenntnis- und wissenschaftstheoretischen Schriften selbst auch deutliche Abgrenzungen zogen. Reichenbach z.B. veröffentlichte gerade in dieser Zeit eine Studie, ${ }^{25}$ in der er die sehr enge Anbindung der Relativitätstheorie an die Vorleistungen Machs, wie diese etwa von Petzoldt betont worden war, ${ }^{26}$ als überzogen und irreführend bezeichnete.

Der Rest der ersten Gruppe führt geradlinig zu Schlicks Formulierung des Relativitätsprinzip für geradlinig gleichförmige Bewegungen, bezogen auf (vom Schlick nicht eigens eingeführte) Inertialsysteme.

Der erste Abschnitt der zweiten Gruppe stellt vor allem eine Art 
prophylaktischer Entgegnung zu verbreiteten Einwendungen dar, auf die Schlick u.a. in den zwanziger Jahren immer häufiger an Stelle des überlasteten Einstein reagierten. Schlick verneint zum einen die oft erhobene These der logischen Widersprüchlichkeit der Relativitätstheorie, ${ }^{27}$ zum anderen weist er die ebenso oft erhobenen Ansprüche auf Begreifbarkeit der Relativitäts- und Gravitationstheorie Einsteins durch die Kategorien des »common sense «28 zurück.

Im folgenden kommt er wieder auf Fragen der Bedeutung von Konzepten wie 'Gleichzeitigkeit' und 'Länge' zurück, wie dies bereits zu Anfang der Fall war.

Zur sprachlichen Form des Schlickschen Aufsatzes ist zu vermerken, daß seinem Text nur sehr vereinzelt an Charakteristika der Wortwahl (z.B. "simultaneousness" S. 90) und des Satzbaues (»they will not be so for another one « S. 91) anzumerken war, daß er nicht von einem Angelsachsen oder Amerikaner verfasst wurde, was vermutlich auf die Mithilfe von Schlicks amerikanischer Ehefrau an der textlichen Ausgestaltung des Manuskriptes zurückzuführen ist. ${ }^{29} \mathrm{Ab}-$ gesehen von Amerika kamen übrigens die meisten Einsendungen aus Deutschland, »doubtless because of the staggering value of $\$ 5,000$ when converted into marks at current rates «, wie die Editoren des Scientific American in ihrem Bericht "How the Einstein Contest worked « am 5. Febr. 1921 berichteten. Und eine Woche zuvor spekulierten J. M. Bird und seine Mitarbeiter: »had it not been for the handicap of writing in a strange language, it is reasonable to assume that the scientists of Germany would have made a showing superior to that of either Americans or British «. Von dieser Tendenz zu oft drastischem Niveauverlust durch sprachliche Ungelenkheiten und Germanismen wurden jedoch insbesondere zwei fremdsprachige Autoren ausgenommen:

De Sitter and Schlick ... were the notable exceptions to this; both showed the ability to compete on a footing of absolute equality with the best of the native product. Dr. Schlick's masterly handling of the language it was that got honorable mention in the editorial of Nov. 6 th. ${ }^{30}$

Dort hatte der Einstein Editor Bird berichtet, ohne den Namen Schlicks zu erwähnen: 
one german essay, in particular, on being examined by our two editors ... provoked the admission that, with the same ideas to express, neither of these gentlemen would dare hope to clothe them in more elegant or more precise English. ${ }^{31}$

Außer Schlicks Passagen wurden nur noch Ausschnitte aus dem Manuskript eines weiteren deutschsprachigen Mitbewerbers, Henry Gartelmann ${ }^{32}$ in die in Buchform veröffentlichte Auswahl einbezogen.

Das originale Manuskript Schlicks muß als verloren gelten, da keine Archivbestände des Scientific American vor 1947 erhalten sind, wie mir Herr Prof. Don Howard (Univ. of Kentucky, Lexington, USA) freundlicherweise mitteilte, der im Zuge eigener Forschungen über Einstein und Schlick ${ }^{33}$ eine Anfrage an die jetztigen Herausgeber des Scientific American gerichtet hatte.

\subsection{Einsteins Gründe zur Nicht-Teilnahme an dem Wettbewerb}

Durch den freundlichen Hinweis von Herrn Prof. Anne J. Kox (Amsterdam) erfuhr ich, daß der Higgins-Preis in einer weiteren einschlägigen Korrespondenz behandelt worden ist. Am 10. September 1920 gratulierte H. A. Lorentz Einstein in der Angelegenheit des Lehrauftrages Einsteins in Leiden, die gerade vom dortigen Universitätsrat abgesegnet worden war. Dann fuhr er wie folgt fort:

Haben Sie schon gelesen, dass man jetzt mit der Relativitătstheorie schon Geld verdienen kann? Ich schliesse hier ein, ${ }^{[34]}$ was ich darüber in einer holländischen Zeitung las. Es wird Sie jedenfalls interessieren.

Eigentlich sollten Sie die 5000 Dollar haben, und die Sc.A. hätte besser getan, Sie um einen Artikel zu bitten und Ihnen dafür die Summe als Honorar anzubieten. Jetzt wollte ich, Sie hätten eine kleine Abhandlung fertig, und wir wären sicher davon, dass die Beurteiler vernünftig genug wären um die zu wählen. Dann würden Sie sich vielleicht dazu entschliessen, selbst in die Arena hinabzusteigen; es ist nicht Ihre Schuld, dass wissenschaftliche Leistungen, wie die Welt Ihnen zu verdanken hat, einen nicht von allen Geldsorgen befreien. Eine Übersetzung ins Englische, wenn es damit in Berlin Schwierigkeiten hätte, könnte ich hier schon besorgen. ${ }^{3 s}$

In einem undatierten Brief aus Hechingen (Süddeutschland) antwortete Einstein darauf wie folgt: 
Hoch verehrter Herr Lorentz!

Ihr ausführlicher Brief hat mich sehr gerührt. ${ }^{[36]}$ Jenes amerikanische Preisausschreiben war mir schon bekannt geworden. Der Urheber selbst hat mir die Ausschreibung zugesandt. Ich muss aber gestehen, dass ich mich sofort dazu entschlossen habe, an dieser Konkurrenz nicht teilzunehmen. ${ }^{[37]}$ Erstens nämlich tanze ich nicht gerne um das goldene Kalb und zweitens habe ich zu dieser Art Tanz so wenig Begabung, dass ich wohl schwerlich Beifall damit finden würde. Eigentliche Sorgen aus Geldmangel habe ich übrigens keineswegs. ${ }^{38}$

Die Worte Lorentz' belegen noch einmal die schlechte Situation des akademischen Durchschnittverdieners, die Einstein nur wegen seiner Sonderstellung in der Preussischen Akademie der Wissenschaften erspart geblieben war. Im übrigen zeigt der warme, ja freundschaftliche Ton dieser Briefe, wie wenig der in der Literatur der Zeit oft zu findende Kontrast 'alte Elektronentheorie - neue Elektrodynamik'39 in der persönlichen Beziehung der beiden Denker Niederschlag gefunden hat, die einander sehr schätzten. ${ }^{40}$

\section{BIBLIOGRAPHIE}

\section{Bird, J. Malcolm}

1920: „Joys and sorrows of the Einstein Editor «, Scientific American 123 (6.11.1920), S. 464.

1921: How the Einstein contest worked*, Scientific American 124 (5.2.1921), S. 102.

1922: Einstein's Theories of Relativity and Gravitation. A selection of material from the essays submitted in the competition for the Eugene Higgins Prize of \$5,000, (ed. J. M. Bird) New York.

Einstein, Albert

1914/77: *Zum Relativitäts-Problem*, Scientia 15 (1914), reprint Scientia 112 (1977), S. 1-16.

1915/25: "Die Relativitātstheorie*, Die Kultur der Gegenwart, 3. Abt.. 1. Bd. Physik, Leipzig u. Berlin, 2. erw. Auflage 1925, S. 783-797.

1917/69: Über die spezielle und die allgemeine Relativitätstheorie, Braunschweig, zit. nach 21. Aufl. 1969.

1929: "Space-time«, Encyclopaedia Britannica, 14. Aufl. Bd. 21, S. 105-108.

Eisler, Rudolf (Hrsg.)

1912: Philosophenlexikon. Leben, Werke und Lehren der Denker, Berlin.

Garteimann, Henry

1920: Zur Relativitäslehre. Eine kritische Betrachtung, Berlin.

1927: "Wirkliche und scheinbare Bewegung“. Annalen der Philosophie 6, S. 284-291.

Goldberg, Stanley

1969: "The Lorentz Theory of Electrons and Einstein's Theory of Relativity«, American Journal of Physics 37, S. 982-994. 
Hentschel, Klaus

1984: Zum Verhälınis Philosophie-Physik anhand der Korrespondenz Schlick-Einstein und ergänzender Dokumente, Magisterarbeit Univ. Hamburg.

1986: „Die Korrespondenz Einstein-Schlick: Zum Verhältnis der Physik zur Philosophie «, Annals of Science 43, S. 475-488.

Howard, Don

1984: "Realism and Conventionalism in Einstein's philosophy of science ", Philosophia Naturalis 21 , S. 284-291.

Juhos Bela

1957: "Moritz Schlick zum 20. Todestag", Studium Generale 10, S. 81-87.

Kox, Anne J.

1988: "Hendrik Antoon Lorentz, the Ether and the General Theory of Relativity«, Archive for History of Exact Sciences 38, S. 67-78.

McCormmach, Russell

1970: "Einstein, Lorentz and the electron theory", Historical Studies in the Physical Sciences 2, S. 41-87.

Mulder, Henk u. van de Velde-Schlick, Barbara (Hrsg.)

1979: Moritz Schlick, Philosophical Papers, 2 Bände, Dordrecht et al.

Petzoldt, Joseph

1921: "Das Verhältnis der Machschen Gedankenwelt zur Relativitätstheorie ". in der 8. Auf von Ernst Machs Mechanik in ihrer Entwicklung historisch-kritisch dargestell, S. $490-517$.

Popper, Sir Karl R.

1953/54: wA note on Berkeley as precursor of Mach«, Brit. Journal for the Philosophy of Science 4, S. 26-36.

Reichenbach, Hans

1921/79: »Der gegenwärtige Stand der Relativitätsdiskussion«, Logos (Prag) 10, S. 316-378; reprint in Gesammelte Werke 3, S. 342-405.

Ruckhaber, Erich

1928: Die Relativitätstheorie widerlegt durch das Widerspruchsprinzip und die natürliche Erkiärung des Micheison-Versuchs, Leipzig.

Schlick, Moritz

1910: "Das Wesen der Wahrheit nach der modernen Logik ", Vierteljahresschrift für wissenschaftliche Philosophie 34, S. 386-477.

1915: "Die philosophische Bedeutung des Relativitätsprinzips«, Zeitschrift für Philosophie und philosophische Kritik 159, S. 129-175.

1917: "Raum und Zeit in der gegenwärtigen Physik «, a) Die Naturwissenschaften 5, S. 161167 u. 177-186; b) als erweitertes Separatum Berlin (2. Aufl. 1919, 4. Aufl. 1922).

1927: »Vom Sinn des Lebens", Symposion 1, S. 331-354.

1930: "Die Wende der Philosophie", Erkenntnis 1, S. 4-11.

1930/84: Fragen der Ethik (Ersterscheinung als Bd. IV der Schriften zur Wissenschaftlichen Weltauffassung), reprint Frankfurt, herausgegeben v. R. Hegselmann.

1933/86: Die Probleme der Philosophie in ihrem Zusammenhang (Vorlesung Wintersemester 1933/34), herausgegeben von H. Mulder, A. J. Kox u. R. Hegselmann, Frankfurt. 
Stadler, Friedrich

1978: "Aspekte des gesellschaftlichen Hintergrunds und Standorts des Wiener Kreises am Beispiel der Universität Wien*, Akten des III. Int. Wingenstein Symposiums Kirchberg am Wechsel 1978, Wien.

1982: Vom Positivismus zur 'Wissenschaftlichen Weltauffassung'. Am Beispiel der Wirkungsgeschichte von Ernst Mach in Osterreich von I895-1934, Wien u. München.

Thedinga. Eddo

1922: Einstein und wir Laien. Wege zu einer neuen Licht-Theorie, Leipzig.

Wittgenstein, Ludwig

192278: Tractatus logico-philosophicus. Logisch philosophische Abhandlungen (Ersterscheinen in Buchform in London), zitiert nach der Ausgabe Frankfurt.

Vogel, Heinrich (Hrsg.)

1970: "Joachim Jungius und Moritz Schlick “, Rostocker Philosophische Manuskripte 3.

Ziegenfuss. Werner und Jung, Gertrud (Hrsg.)

1949/50: Philosophen-Lexikon. Handwörterbuch der Philosophie nach Personen, 2 Bände, Berlin.

\section{ANMERKUNGEN}

1. Dargeiegt in Schlick 1915, 1917a und b und vielen weiteren Schriften; vgl. Hentschel 1984 und 1986 sowie Howard 1984 und Vogel (Hrsg.) 1970.

2. Morizz Schlick Bibliography in Mulder et al. 1979, S.515-518 sowie in Schlick 1933/86, S. 255-258.

3. Eisler 1912.

4. Siehe Ziegenfuss und Jung 1949/50.

5. Vgl. z.B. Juhos 1957 oder Hentschel 1984, Kap. 10, S. 114-121.

6. Siehe dazu das $*$ Vorworta von Ziegenfuss 1949.

7. Anspielung auf den Titel von Schlick 1930/84.

8. Vgl. z.B. Schlick 1934.

9. Vgl. z.B. Schlick 1927.

10. Vgl. z.B. Schlick 1930.

11. So z.B. in Schlicks Bestimmung der wsogenannten rationalen Wahrheiten* als Tautologien und in der Feststellung: "Die Philosophie ist keine Wissenschaft, obwohl sie alle Wissenschaften durchdringt « - vgl. Wittgenstein 1922/78 Satz 4.46ff. bzw. 4.111 für Parallelstellen.

12. So der Untertitel von Ziegenfuss und Jung 1949/50. Für die Genehmigung zur Wiedergabe der von Schlick verfassten Passage in Bd. II (1950), S. 462-463 danke ich insb. Herrn Mahr i.A. des Verlages de Gruyter \& Co., Berlin.

13. Text der Ausschreibung in Bird 1922, S. Sff. sowie im Scientific American 123 (10. VII. 1920), S. 32.

14. Veröffentlicht mit Genehmigung von A. J. Kox im Auftrag der Vienna Circle Foundation, Amsterdam und von Mrs. Margot Cohn, Dept. of Manuscripts and Archives. The Jewish National \& Hebrew Library, Jerusalem; Dokument Nr. 21-580.

15. Mit Schljck 1910.

16. Zur (schlechten) Lehrstuhlsituation der Zeit vgl. Stadler 1978. 
17. Vgl. dazu den Bericht zur Arbeit der Juroren in Bird 1922. S. $12 f$.

18. Siehe Anm. 13.

19. Sogenannte "Composite chapters« (Bird 1922, S. xi). Die Autorschaft der einzelnen Abschnitte wurde dabei jeweils durch eckige Klammern und Nummern am Ende jedes Abschnittes kenntlich gemacht, wobei die Nummern auf die S. xi. f. aufgelisteten Eingangsnummern der Manuskripte zunückverweisen.

20. Die Wiedergabe dieses Schlick-Textes erfolgt, wie auch die der Selbstbiographie, mit freundlicher Genehmigung von A.J. Kox i.A. der Vienna Circle Foundation, die die Publikationsrechte der Schriften Schlicks innehat.

21. Diese Zwischenüberschrift im Schlick-Text wurde vermutlich vom Editor J. Bird eingeschoben, der die collagierten Sammelkapitel dadurch übersichtlicher zu machen suchte.

22. Hier schob Bird eine ergänzende Bemerkung von sich ein; der nächste Abschnitt Schlicks beginnt jedoch mit der zweiten Hälfte dieses Satzes, die für sich genommen am Ende dieses Abschnittes irreführend ist.

23. Vgl. dazu Popper 1953/54 und Hentschel 1984, Kap. 2.6 und 11 sowie die dort zitierte Literatur.

24. So z.B. durch die Gründung des 'Vereins Ernst Mach'; siehe dazu Stadler 1982.

25. Rejchenbach $1921 / 79$.

26. Z.B. Petzoldt 1921.

27. Als ein Beispiel sei genannt Ruckhaber 1928.

28. Vgl. 2.B. Thedinga 1922, S. 53f.

29. Diesen Hinweis auf Schlicks Ehefrau, mit der Schlick übrigens in Englisch korrespondierte, verdanke ich Herm Prof. Anne J. Kox (Instituut voor theoretische Fysika, Universiteit van Amsterdam).

30. Als Autor zeichnete $»$ the Einstein editor $\kappa(=\mathrm{J}$. Malcolm Bird 1921). Das vorangegangene Zitat stammt aus dem Scientific American vom 29. Jan. 1921, S. 82.

31. Bird 1920.

32. Vgl. z.B. Gartelmann 1920 und 1927.

33. Siehe Howard 1984.

34. Lorentz legte seinem Brief eine vierseitige handschriftliche Abschrift der komplizierten Teilnahmebedingungen für den Higgins-Wettbewerb bei, die hier nicht wiedergegeben werden soll.

35. Veröffentlicht mit Genehmigung von Miss F. van Anrooij M.A. im Auftrag des Algemeen Rijksarchief, Tweede Afdeling ('s-Gravenhage) [Lorentz-NachlaB] und unter Zustimmung von Mrs. Margot Cohn (Anm. 14) [Einstein-NachlaB, Dokument Nr. 16-526].

36. Als Fußnote Einstein am unteren Ende der ersten Seite seines Antwortbriefes: "Ganz besonders Ihr Anerbieten bezüglich einer Übersetzung in die englische Sprache«.

37. Einstein hat sich jedoch gelegentlich durchaus selbst um eine populäre Darstellung seiner Relativitāts- und Gravitationstheorie bemüht. Vier Beispiele für verschiedene Texttypen (Zeitschriftenartikel, Buch, Handbuch- und Lexikonartikel) sind: Einstein 1914/77, 1917/69, 1915/25 und Einstein 1929.

38. Veröffentlicht mit Genehmigung der Lorentz- und Einstein-papers (vgl. Anm. 14 und 35), Dokument Nr. 16-531.

39. Ein Beispiel wäre erneut Ruckhaber 1928, S. 27. Vgl. auch die Studien von Goldberg 1969 sowie Kox 1988 und dort zitierte weitere Arbeiten von Schaffner, A. I. Miller, Sahar u.a.

40. Siehe dazu vor allem McCormmach 1970. 